УДК $811.112 .2 ’ 373.2$

DOI https://doi.org/10.26661/2414-1135-2021-81-1-25

\title{
МЕТОНІМІЧНА ВТОРИННА НОМІНАЦІЯ АНТРОПОНІМІВ У НІМЕЦЬКІЙ МОВІ
}

\author{
Кійко С. В. \\ доктор філологічних наук, професор, \\ завідувач кафедри германського, загального і порівняльного мовознавства \\ Чернівецький начіональний університет імені Юрія Федьковича \\ вул. Садова, 5, Чернівиі, Україна \\ orcid.org/0000-0003-4964-7043 \\ s.kiyko@chnu.edu.ua \\ Лex O. C. \\ кандидат філологічних наук, доцент, \\ дочент кафедри германського, загального і порівняльного мовознавства \\ Чернівецький національний університет імені Юрія Федьковича \\ вул. Садова, 5, Чернівиі, Украӥна \\ orcid.org/0000-0003-4070-4742 \\ o.lekh@chnu.edu.ua
} Ключові слова: власні назви,
антропоніми, метонімія,
семантичне перенесення,
метонімічні трансформаціі.
У статті розглянуто особливості семантичних переносів із власних на омонімічні загальні назви на прикладі антропонімів сучасної німецької мови. Детально досліджено механізми й описано регулярні типи метонімічного переносу з антропонімів на апелятиви. Метонімію потрактовано як перенесення найменування, логічну основу якого становить входження обсягу одного поняття в обсяг іншого на підставі психологічних асоціацій, що відображають каузальні, атрибутивні, просторові, темпоральні та партитивні зв'язки, які об'єктивно існують між предметами. 3 огляду на це у роботі виокремлено п'ять типів метонімічного переносу: каузальний, за якого вихідні значення метонімів мають у словниковому тлумаченні семи «дія», «стан», «процес», «подія», «об’єкт дії» та «інструмент»; атрибутивний, якщо метоніми мають семи «якість», «властивість», «ознака»; локальний, коли семантична структура іменників містить семи «територія», «місце», «приміщення»; темпоральний, за якого провідними є семи «час», «період»; партитивний, зумовлений взаємодією понять частини та цілого.

Серед метонімічних трансформацій антропонімів переважають каузальні перенесення, зумовлені причинно-наслідковим зв'язком між поняттями суміжних об'єктів. Рідше виявлено атрибутивний тип метонімічного перенесення, зумовлений асоціацією понять ознаки та суб'єкта / об'єкта, що володіє ознакою. Приклади локальної, темпоральної та партитивної метонімії трапляються спорадично. У вибірці наявні також випадки ситуативного метонімічного перенесення, суть якого полягає в перенесенні антропоніма на певний предмет, зв'язок між якими опосередкований ситуативно. Ще одним способом утворення апелятивів 3 антропонімів $є$ паронімічна атракція, котра виникає на основі зближення співзвучних слів. Носій імені, найчастіше відома особа, асоціюється фонетично зі спільнокореневими або спільнозвучними словами різних частин мови, що водночас зумовлено деякими особливостями носія імені, тобто спостерігаємо подвійну мотивацію найменування. 


\title{
METONYMIC SECONDARY NOMINATION OF ANTHROPONYMS IN MODERN GERMAN
}

\author{
Kiyko S. V. \\ Doctor of Philological Sciences, Professor, \\ Head of the Department of German, General and Comparative Linguistics \\ Yuriy Fedkovych Chernivtsi National University \\ Sadova str., 5, Chernivtsi, Ukraine \\ orcid.org/0000-0003-4964-7043 \\ s.kiyko@chnu.edu.ua
}

Lekh O. S.

Candidate of Philological Sciences,

Associate Professor at the Department of German, General and Comparative Linguistics

Yuriy Fedkovych Chernivtsi National University

Sadova str., 5, Chernivtsi, Ukraine

orcid.org/0000-0003-4070-4742

o.lekh@chnu.edu.ua

Key words: proper names, anthroponyms, metonymy, semantic transfer, metonymic transformations.
The article deals with some pecularities of semantic shifts from proper names to homonymic common words in terms of anthroponyms in modern German. Mechanism and regular types of metonymy transfers from anthroponyms to appellatives are examined in detail. Metonymy is interpreted as the transfer of a name, the logical basis of which is the entry of the volume of one concept into the volume of another on the basis of psychological associations that reflect causal, attributive, spatial, temporal and partitive connections existing between objects. In view of this, 5 types of metonymic transfer are distinguished in the work: causal, in which the original meanings of metonyms have in the dictionary interpretation of action, state, process, event, object of action and tool; attributive, if metonyms mean quality, property, feature; local, when the semantic structure of nouns contains sems of territories, places, premises; temporal, in which the leading are sems time, period; partitive, which is due to the interaction of the concepts of part and whole.

Among the metonymic transformations of anthroponyms, causal transfers predominate due to the causal relationship between the concepts of adjacent objects. Less often, an attributive type of metonymic transference is found, due to the association of the concepts of the sign and the subject / object that has the sign. Examples of local, temporal and partitive metonymy occur sporadically. There are also cases of situational metonymic transfer in the sample, the essence of which is to transfer the anthroponym to a certain subject, the connection between which is situational. Another way of forming appellations from anthroponyms is paronymic attraction, which arises by convergence of consonant words. In this case, the bearer of the name, most often a wellknown person, is associated phonetically with cognate or co-sounding words of different parts of speech, when we observe a double motivation of the name.
Постановка проблеми. Власні назви (ВН) це особливий пласт у лексичній системі мови, для якого характерна індивідуальна закріпленість за позначуваним об’єктом. 3 погляду теорії референції ВН не мають інтенсіонала, проте мають екстенсіонал - множину носіїв певного імені. Основною для них є функція референції, а не характеризації: інваріантне значення ВН зводиться до можливості надавати референцію, але не до детального визначення іiі умов. Іншими функціями ВН $є$ комунікативна (коли ім'я, відоме співрозмовнику, служить основою повідомлення), апелятивна, експресивна [3, с. 8-13; 6, с. 64-66]. На відміну від загальних назв, ВН позбавлені конотації та не мають зна- 
чення, тобто їх не можна визначити без звертання до денотата - реального носія імені. Іншими словами, семантика ВН - це їхня вказівка на певний предмет, явище, особу. Крім того, визначальною рисою ВН є їхня постійна, обов'язкова вторинність найменування, тобто ВН - це завжди останне найменування в низці родо-видових ознак, як-от: жива істота $\rightarrow$ людина $\rightarrow$ чоловік $\rightarrow$ українець $\rightarrow$ чернівчанин $\rightarrow$ Іван Петренко.

Відхиленням від основного правила вживання ВН $є$ приклади омонімії, коли ВН вживається в мовленні як загальна. Причиною цього є, очевидно, наявність у структурі значення ВН мінімальної кількості категорійних сем, за рахунок чого вона здатна наповнюватися конотативною інформацією (набувати асоціативних і потенційних сем). Таким чином, ВН трансформується в апелятив, втрачає індивідуальну закріпленість і позначає не одну особу, а цілий клас осіб. Так, ім'я Іван іноді може вживатися для позначення росіянина, Джон - американця, Жан - француза тощо, оскільки ці слова є досить поширеними іменами чоловіків у відповідних мовних спільнотах. Кожна із кличок собак Барбос, Тузик, Сірко стосується окремої собаки, але завдяки тому, що це розповсюджені собачі клички, можливий їх перехід у загальні назви: слова барбос, тузик, сірко втрачають індивідуалізуючу функцію і можуть указувати на будь-якого собаку. Як видно з наведених прикладів, у ВН слід розрізняти пряму (первинну) та переносну (вторинну) номінативні функції. $\mathrm{У}$ прямій номінативній функції ВН слугує для вказівки на той предмет, якому вона присвоєна в індивідуальному порядку. Переносна номінативна функція характеризується переносом найменування на інший предмет, внаслідок чого ВН здатна приписувати певні властивості низці об'єктів.

Аналіз останніх досліджень i публікацій. Проникнення омонімії до пропріального прошарку лексики викликає сумнів у деяких дослідників, зокрема через редукцію апелятивної семантики ВН і перевагу об'єктно-номінативного зв'язку (звукової послідовності фонем) над семантичним у виділенні значень основи [2, с. 13-15]. Дослідники окремих класів ВН, фіксуючи наявність у них омонімії, намагаються пояснити іï шляхом інтерпретації терміна «омоніми» як співвідношення фонетично тотожних слів із різними значеннями, які виникли внаслідок дивергенції або випадкової фонетичної конвергенції. Деякі лінгвісти вважають, що перехід ВН у загальні ніколи не відбувається повністю. Так, М.Я. Блох i T.M. Семенова зазначають, що транспозитивна деформація лексико-граматичної опозиції «ВН $\rightarrow$ загальна назва» веде до виникнення напівзагальних ВН, які перебувають на певній стадії переходу в загальні назви та мають змішані лексико-грама- тичні властивості (цит. за [5, с. 225]). На противагу цьому інші лінгвісти вважають, що ВН може повністю втрачати зв'язок зі своїм референтом i функціонувати як широкозначні демографічні номінації Mann і Frau. Як доповнення до розширення обсягу лексичного значення ВН спостерігаємо приріст лексичного значення за рахунок конотативних сем. ВН перетворюється на лексему, яка виражає особливе не нейтральне ставлення до референта (денотата). Такими $є$ в німецькій мові номінації Adam і $E v a$, які в розмовному мовленні вживають як жартівливі апелятиви: Hübsche Eva sucht gut aussehenden, liebevollen Adam.

Омонімія власних і загальних назв-іменників розглядається у низці робіт, проте на матеріалі декількох найбільш яскравих прикладів 3 одного-двох розрядів ВН. Так, Ф.А. Литвин відносить до омонімів такі позначення, як Захід «країни західної Європи» та «сторона світу» [6, с. 64-68]. О.С. Ахманова вважає такі випадки, як Геркулес «міфологічний герой» і геркулес «крупа», Зефір «західний вітер» і зефір «вид солодощів» прикладами вираженої омонімії, тобто вживання одного й того самого фонетичного й орфографічного комплекса для позначення різних предметів чи явищ [2, с. 133]. У дослідженні Р.А. Абрамова головну увагу зосереджено на переході одного поняття в інше на підставі причинних, означальних, локативних i ситуативних зв'язків, як-от: антропонімів у зооніми (Маська, Васька - розмовні варіанти чоловічих імен і кличок тварин), антропонімів у топоніми (Володимир - чоловіче ім'я та розмовна назва міста Володимир-Волинський), топонімів у зооніми (Дніпро, Дунай як назви річок і клички коней або собак) тощо $[1$, c. 12], проте проблема омонімії розглянута у вказаних працях переважно з позиції тотожності предмета, особи, місця тощо, позначених ВН.

Постановка завдання. Мета нашого дослідження - розглянути особливості омонімії власних i загальних назв i механізм метонімічного семантичного переносу з ВН на загальну назву на основі суцільної вибірки апелятивів, похідних від $\mathrm{BH}$, із тлумачних словників німецької мови. Розгляд омонімії обмежимо антропонімами, оскільки вони з історичного погляду первинні серед інших ВН. Крім того, соціальна значимість людини досить очевидна, що проявляється в постійній діяльності $з$ найменування всього сущого. Матеріалом дослідження слугують 145 антропонімів, омонімічних до загальних назв, виписані із тлумачних словників німецької мови. Серед досліджуваних антропонімів переважають імена людей (78 лексем), як-от: Hans, Michel, Liese, далі йдуть прізвища (58): Casanova, Meier, Stresemann і прізвиська (9): Teddy, Grog, Rüpel. У роботі дотримуємося поділу ВН на одиничні та множинні [3, с. 39]. 
Кількість одиничних антропонімів становить 100 імен, як-от: Diesel, Cäsar, Zeppelin, кількість множинних антропонімів дорівнює 45: Klaus, Otto, Heinrich. Попередні результати вказують на те, що одиничні та множинні антропоніми мають різну здатність до семантичних переносів [5, с. 216-224]. Оскільки матеріалом наших попередніх досліджень слугували метафоричні переноси антропонімів [5, с. 224-251], зупинимося детальніше на особливостях метонімічної вторинної номінації антропонімів.

Виклад основного матеріалу. Під антропонімом розуміють власну назву, (офіційно) присвоєну окремій людині як іï розпізнавальний знак. Сюди належать імена, по-батькові, прізвища, прізвиська, псевдоніми, криптоніми (таємні імена), андроніми (найменування дружини прізвищем чоловіка), гінеконіми (найменування чоловіка прізвищем матері чи дружини), патроніми (найменування людини від імені чи прізвиська батька або предків) [3, с. 38].

Метонімія як спосіб вираження пов'язаних одна 3 іншою властивостей полягає в тому, що назва однієї властивості, яка постійно виступає спільно 3 іншою, переноситься на іншу. 3 огляду на семантичну структуру слова метонімія грунтується на семній динаміці: усуненні інтегральної семи та заміні їі диференційною. У когнітивній семантиці метонімія пояснюється рухом знака 3 одного елемента когнітивної моделі (пропозиції, фрейму) до іншого. Г. Редден і 3. Ковечез кваліфікують метонімію як когнітивний процес, за якого одна концептуальна сутність забезпечує ментальний доступ до другої концептуальної сутності в межах певного домена. Когнітологи вважають основною функцією метонімії інтерференційну як функцію логічного виведення [7, с. 7]. У дослідженні розглядаємо метонімію як перенесення найменування, логічну основу якого становить входження обсягу одного поняття в обсяг іншого на підставі психологічних асоціацій, що відображають каузальні, атрибутивні, просторові, темпоральні та партитивні зв'язки, які об'єктивно існують між предметами. Підставою для віднесення омонімічних антропонімів і апелятивів до тієї чи іншої групи метонімічних переносів $€$ аналіз статей тлумачних словників.

Ми виокремлюємо п'ять типів метонімічного переносу: 1) каузальний, за якого вихідні значення метонімів мають у словниковому тлумаченні семи дія, стан, процеес, подія, об'єкm дї та інструмент; 2) атрибутивний, якщо метоніми мають семи якість, властивість, ознака; 3) локальний, коли семантична структура іменників містить семи територія, місце, приміщзення; 4) темпоральний, за якого провідними є семи час, періoд; 5) партитивний, зумовлений взаємодією понять частини та цілого.
Серед метонімічних трансформацій антропонімів переважають каузальні переноси, зумовлені причинно-наслідковим зв'язком між поняттями суміжних об'єктів. Причина та наслідок утворюють безперервну єдність, відображену у вигляді певних асоціацій між поняттями. Систему каузального зв'язку становлять у нашому випадку суб'єкт дії, об'єкт дії та їі результат. Ми виявили сім регулярних моделей цього типу: 1) «прізвище дослідника $\rightarrow$ фізична (хімічна, математична) величина», тобто перенесення прізвищ відомих фізиків, хіміків, математиків на відкриті ними сталі або змінні величини, одиниці виміру (22 омопари): Angström «ангстрем», Ampere «ампер», Becquerel «бекерель», Coulomb «кулон», Fahrenheit «фаренгейт», Gauß «гаус», Gray «грей», Henry «анрі», Hertz «герц», Joule «джоуль» тощо; 2) «прізвище винахідника $\rightarrow$ назва винаходу» (7 омопар), тобто перенесення прізвища інженера або конструктора на його технічний винахід: Diesel «дизель» (на честь німецького винахідника Р. Дизеля), Kardan «карданний вал» (від імені італійського інженера Г. Кардано), Nonius «масштабна лінійка» (на честь португальського математика П. Нунеса), Browning «браунінг» (на честь американського інженера Дж. М. Браунінга), Kremser «кремзер; лінійка» (на честь винахідника кінного фургону для перевезень пасажирів C. Кремзера), der / das Makadam «макадам» (вид доріжного покриття на честь інженера Дж. МакАдама), Zeppelin «повітряна куля» (на честь конструктора фон Цеппеліна); 3) «ім'я або прізвище виробника $\rightarrow$ його вироби» (4 омопари): Colt «кольт» (від імені американського промисловця C. Кольта), Stetson «фетровий капелюх із широкими крисами» (від імені американського підприємця Й.Б. Стетсона), Strass «страз» (від імені французького ювеліра Г.Ф. Страза), Baedecker «путівник» (від імені німецького видавця та книготорговця К. Бедекера); 4) «ім'я або прізвище спортсмена $\rightarrow$ його досягнення» (4 омопари): Axel (вид стрибка на честь норвезького фігуриста Акселя Паульсена), Lutz (вид стрибка на честь австрійського фігуриста А. Лютца); 5) «ім'я, прізвище або прізвисько автора $\rightarrow$ винайдений ним новий напій» (3 омопари): Grog «грог» (від прізвиська англійського адмірала Вернона, котрий наказав давати матросам розбавлений водою ром), Cointreau «апельсиновий лікер» (на честь французьких виноробів Контре), Kir «вид аперитива» (від імені бургомістра французького міста Діжон Ф. Кіра, який винайшов новий напій спеціально для прийому гостей у меріï); 6) «ім'я або прізвище селекціонера $\rightarrow$ вирощений ним новий сорт овочів або фруктів» (2 омопари): James Grieve «Джеймс Грів» (сорт столових яблук від імені селекціонера Дж. Гріва), Сох «Кокс» (сорт 
зимових яблук від імені селекціонера Р. Кокса); 7) «ім'я, прізвище або прізвисько кухаря $\rightarrow$ винайдена ним страва» (2 омопари): Julienne «жульєн» (від імені французької кухарки Жюльєн Леотард), Nacho «кукурудзяне печиво» (від імені мексиканського кухаря Ігнаціо Анайі).

Менш регулярними $€$ переноси за моделями «ім'я або прізвище автора $\rightarrow$ написаний ним твір»: Pitaval «збірка судових справ і кримінальних історій» (на честь французького юриста Ф. де Пітаваля, що описав найвідоміші випадки зі своєї практики); «ім'я або прізвище кінолога $\rightarrow$ вирощена ним нова порода собак»: Dobermann «доберман» (на честь німецького кінолога Ф. Добермана); «ім'я або прізвище дослідника $\rightarrow$ відкрита ним закономірність»: Pythagoras «теорема Піфагора». Трапляються також випадки метонімічного перенесення на назви винаходу імені не винахідника (творця, селекціонера, дизайнера), а відомої людини (політичного діяча, філософа, літератора, художника, актора), або членів сім'ї, дітей, коханих тощо, наприклад: Jonathan «джонатан» (сорт зимових яблук, названий селекціонерами на честь відомого американського юриста та правозахисника Джонатана Хасбрука), Müller-Thurgau (сорт винограду на честь швейцарського ботаніка та фізіолога Г. Мюллера 3 міста Тюргау), Landseer «ньюфаундленд» (на честь англійського художника Е.Г. Лендсера, котрий малював переважно собак цієї породи), Tony «Тоні» (щорічна театральна відзнака на честь американської актриси Антуанетти Перрі), Barbie «Барбі» (назва ляльки на честь доньки американських дизайнерів Хендлерів). Цікавими $\epsilon$ випадки метонімічного перенесення імені французького винахідника прядильної машини Й.-М. Жакарда не на винахід, а на тканину, яку випряли на цій машині: der Jacquard «жакард».

Атрибутивний тип метонімічного перенесення зумовлений асоціацією понять ознаки та суб'єкта / об'єкта, що володіє ознакою. Перехід власних назв у загальні відбувається тут за такими моделями: 1) «ім'я або прізвище людини $\rightarrow$ iï вирізняльний предмет одягу» (4 омопари), як-от: Spenzer «спенсер» (короткий приталений піджак на честь англійського графа Дж. Спенсера), Raglan «реглан» (вид пальто на честь лорда Реглана), Stresemann «чоловічий костюм-трійка» (на честь рейхсканцлера Г. Штреземанна); 2) «ім'я людини $\rightarrow$ позначення групи людей із відповідною ознакою»: Cäsar «кайзер» (на честь римського імператора Юлія Цезаря), Ganimed «слуга, офіціант» (похідне від імені слуги Зевса, що розливав напої); 3) «ім'я або прізвище людини $\rightarrow$ iï вирізняльний предмет туалету», як-от: Wilhelm «перука» (на честь прусського короля Фрідріха
Вільгельма, за часів правління якого були в моді перуки); 4) «ім'я людини $\rightarrow$ iї улюблена страва»: Charlotte «шарлотка» (на честь дружини англійського короля Георга III Софії Шарлотти).

До локальної метонімії відносимо іменники, семантична структура яких містить семи «територія», «місце», «приміщення», як-от: Hades «підземне царство» (похідне від імені грецького бога підземного царства Аїда < грецьк. Hádes). У вибірці трапилися випадки так званого ситуативного метонімічного перенесення, що не згадується в інших дослідників. Суть його полягає в перенесенні антропоніма на певний предмет, зв'язок між якими опосередкований ситуативно. Так, позначення Teddy «ведмедик (дитяча іграшка)» походить від зменшувального імені американського президента Теодора Рузвельта, котрий на полюванні в Міссісіпі у 1902 р. відмовився стріляти у ведмежа, яке загнали для нього члени мисливської спілки. Іншим прикладом $€$ метонімічне перенесення прізвища вождя латиноамериканського визвольного руху С. Болівара на позначення валюти Венесуели: Bolivar.

Ще одним способом утворення апелятивів 3 антропонімів $є$ паронімічна атракція, що виникає на основі зближення співзвучних слів, як-от: er studiert Kotzebues Werke «його нудить» (< A. Kotzebue - німецький реакційний письменник-моралізатор; kotzen «нудити; блювати»). Носій імені, найчастіше відома особа, асоціюється фонетично зі спільнокореневими або спільнозвучними словами різних частин мови, це водночас зумовлено деякими особливостями носія імені, тобто спостерігаємо подвійну мотивацію найменування.

Висновки і перспективи. Як видно 3 наведених прикладів, імплікування енциклопедичної інформації, пов'язаної з денотатами-антропонімами, привело до створення містких символічних співзначень імен. Вони виконують функції типізатора, характеризатора об'єкта, ознаки, дії, способу, часу, місця. Метонімічний перехід антропонімів в апелятиви пов'язаний насамперед із процесами семантико-синтаксичного, контекстного, ситуативно-мовленнєвого плану. За метонімічного переносу ознака береться з області інтенсіонала антропоніма та набуває статусу гіпосеми похідного значення. Конфігурація метонімічного перенесення $\epsilon$ асиметричною: спостерігається висунення корелята та згасання референта.

Перспективним вважаємо дослідження регулярних метафоричних і метонімічних переносів 3 інших видів власних назв (топонімів, зоонімів, космонімів, хрематонімів тощо) на загальні назви, що дозволить виявити спільне та відмінне в механізмах семантичних переносів як серед різних груп власних назв, так і серед апелятивів загалом. 


\section{ЛІТЕРАТУРА}

1. Абрамов Р.А. Міжонімна омонімія (омонімія власних назв) в сучасній українській мові. Записки з ономастики. 2013. Вип. 16. С. 18-23.

2. Ахманова О.С. Очерки по общей и русской лексикологии. Москва : Книжный дом «Либроком», 2009. 296 с.

3. Ермолович Д.И. Имена собственные на стыке языков и культур. Москва : Валент, 2001.200 с.

4. Желєзняк I.M. Про деякі лінгвістичні ознаки власних назв. Мовознавство. 2001. № 1. C. $13-17$.

5. Кійко С.В. Омонімія в мові і мовленні. Чернівці : Родовід, 2014. 544 с.

6. Литвин Ф.А. Многозначность слова в языке и речи. Москва : КомКнига, 2005. 120 с.

7. Radden G., Kovecses Z. Towards a Theory of metonymy. Metonymy in Language and Thought. Amsterdam : J. Benjamins, 1999. P. 7-59.

\section{REFERENCES}

1. Abramov R.A. (2013). Intenonym homonymy (homonymy of proper names) in the modern Ukra- inian language [Mizhonimna omonimiia (omonimiia vlasnykh nazv) v suchasnii ukrainskii movi]. Zapysky z onomastyky. Vyp. 16. S. 18-23.

2. Akhmanova O.S. (2009). Essays on general and Russian lexicology [Ocherky po obshchei i russkoi leksikologii]. Moskow: Librokom, 2009. 296 s.

3. Ermolovych D.Y. (2001). Proper names at the junction of languages and cultures [Imena sobstvennye na styke yazykov i kultur]. Moskow: Valent, 2001. $200 \mathrm{~s}$.

4. Zheliezniak I.M. (2001). About some linguistic features of proper names [Pro deiaki linhvistychni oznaky vlasnykh nazv]. Movoznavstvo. № 1. S. 13-17.

5. Kiyko S.V. (2014). Homonymy in language and speech [Omonimiia v movi i movlenni]. Chernivtsi: Rodovid, 2014. 544 s.

6. Litvin F.A. The ambiguity of the word in language and speech [Mnogoznachnost slova $\mathrm{v}$ yazyke $\mathrm{i}$ rechi]. Moskva: KomKnyha, 2005. 120 s.

7. Radden G., Kovecses Z. Towards a Theory of metonymy. Metonymy in Language and Thought. Amsterdam: J. Benjamins, 1999. P. 7-59. 